Alexander E. Kentikelenis

Trinity College, University of Oxford

\title{
Structural Adjustment and Health: A conceptual framework and evidence on pathways
}

\begin{abstract}
Economic reform programs designed by the International Monetary Fund and the World Bankso-called 'structural adjustment programs' - have formed one of the most influential policy agendas of the past four decades. To gain access to financial support from these organizations, countries - often in economic crisis - have reduced public spending, limited the role of the state, and deregulated economic activity. This article identifies the multiple components of structural adjustment, and presents a conceptual framework linking them to health systems and outcomes. Based on a comprehensive review of the academic literature, the article identifies three main pathways through which structural adjustment affects health: policies directly targeting health systems; policies indirectly impacting health systems; and policies affecting the social determinants of health. The cogency of the framework is illustrated by revisiting Greece's recent experience with structural adjustment, drawing on original IMF reports and secondary literature. Overall, the framework offers a lens through which to analyze the health consequences of structural adjustment across time, space and levels of socioeconomic development, and can be utilized in ex ante health impact assessments of these policies.
\end{abstract}

\section{Keywords}

Structural adjustment; health systems; health outcomes; International Monetary Fund; World Bank; neoliberalism; social determinants of health; political economy of health. 


\section{Introduction}

Thirty years ago, UNICEF published a landmark report documenting how 'structural adjustment' programs of the International Monetary Fund (IMF) and the World Bank affected population health (Cornia et al., 1987). Following the debt crises of the early 1980s, such programs achieved notoriety for requiring low- and middle-income countries to move away from state-led development models towards free market-oriented ones, premised on reducing public spending, limiting the role of the state, and deregulating economic activity (Babb and Kentikelenis, 2017). But, according to recent reports and public statements of these powerful international financial institutions (IFIs), that era has long since passed (e.g., IMF, 2014). After the turn of the millennium, tarnished structural adjustment programs were replaced by pro-poor 'poverty reduction and growth' loans that purportedly devoted attention to social policies and vulnerable populations, and considered input of local authorities and civil society.

Is the structural adjustment policy paradigm indeed irrelevant today? Since the onset of the global financial crisis in 2008, the IMF and the World Bank reemerged as key actors shaping the policy trajectory of countries in economic crisis, and critics have pointed to the many parallels with the IFIs' previous modus operandi (Babb and Kentikelenis, 2017; Labonté and Stuckler, 2016; Patel and Phillips, 2015; Ruckert and Labonté, 2012a). In this context, long-standing concerns about the effects of these policies on health systems and outcomes have returned to the fore (De Vogli, 2011; Greer, 2014; Kentikelenis et al., 2016; Labonté and Stuckler, 2016; Ortiz et al., 2011; Pfeiffer and Chapman, 2010; Ruckert and Labonté, 2012a).

This article identifies the multiple components of IMF and World Bank structural adjustment programs, and presents a conceptual framework linking them to health systems and outcomes. Drawing on a comprehensive review of the academic literature, the article identifies three main pathways through which structural adjustment affects health: policies directly targeting health systems; policies indirectly impacting health systems; and policies affecting the social determinants of health. These general pathways are relevant to the structural adjustment experience of countries across time, space, and level of socioeconomic development. The cogency of this framework is illustrated with empirical material drawn from Greece’s recent experience.

The framework presented here has implications for designing economic reform packages that are sensitive to public health. The pathways identified can be scrutinized by policymakers - country officials, international organization staff, and donors - in ex ante estimations of how different policies may affect health systems and outcomes. The World Bank's recent move towards incorporating a health safeguard in its investment projects is a first step in this direction (World Bank, 2016), and can be also taken up by other IFIs by institutionalizing health impact assessments for their programs (Stuckler et al., 2010a).

\section{A short introduction to structural adjustment}

The term 'structural adjustment' is shorthand for the wide array of reforms designed to effect a fundamental, comprehensive and enduring overhaul of a country's policy arrangements (Pfeiffer and Chapman, 2010). Commonly, these policies are bundled in ambitious policy packages, that are 'directed at the four “....ations”- stabilization, liberalization, deregulation, privatization' (Summers and Pritchett, 1993, p. 383). Stabilization entails fiscal, monetary and exchange rate policies aiming to restore balance-of-payments and currency stability, and control inflation; these include what are known as fiscal consolidation measures or - simply - 'austerity' (Stuckler and Basu, 2013). Trade and capital account liberalization reduces barriers to trade, and facilitates foreign direct investment. Economic deregulation limits state interference in the workings of the free market; for example, by 
adopting business-friendly legislation. Finally, state-owned enterprise and natural resource privatization is intended to improve economic performance of industries hitherto sheltered from market forces.

Even though structural adjustment targets national or sub-national policies and institutions, the key agents propagating this policy agenda operate beyond the state level: IFIs design, administer and oversee reforms through loans that come with strings attached. Borrowing governments—often facing dire economic circumstances - commit to implementing a range of policy reforms, collectively known as 'conditionality' (Babb and Carruthers, 2008; Greer, 2014). Among IFIs, the IMF and the World Bank have been the key agents promoting the structural adjustment agenda, as outlined in Box 1.

\section{[Box 1 here]}

Similarities in Fund- and Bank-mandated structural adjustment across time and space should not be overstated (Greer, 2014). These organizations design tailored programs that reflect country specificities and depend on a host of political-economic factors (Kentikelenis et al., 2016). Nevertheless, constant across the experiences of low-, middle-, and high-income countries with structural adjustment programs is the compliance tool used-conditionality-and the free marketorientation of mandated reforms (Babb and Carruthers, 2008; De Vogli, 2011; Greer, 2014; Kentikelenis et al., 2016; Labonté and Stuckler, 2016; Pfeiffer and Chapman, 2010; Ruckert and Labonté, 2012a).

\section{Disentangling the ties that bind: structural adjustment and health}

To trace how structural adjustment affects health policy and outcomes, this article draws on a comprehensive literature review. A search on the Web of Science database yielded 720 articles ("structural adjustment" OR "International Monetary Fund" OR "World Bank" AND health). Articles were considered for inclusion if they were: (i) descriptive or analytic observational studies, commentaries, or reviews; (ii) published in the fields of public health or the sociology of health; and (iii) published in English prior to 1 August 2016. All titles and abstracts were assessed, and 93 studies were directly relevant for the present article. Reference lists of these articles and Google Scholar searches revealed additional literature. Only the most relevant and recent studies are cited here. The method used is a narrative synthesis (Mays et al., 2005), in order to map pathways, populate the framework, and identify directions for future research.

As outlined in Figure 1, analysis of the reviewed studies found evidence of three general pathways through which structural adjustment affects health. Several past works have examined related questions of how economic crises affect health (e.g., Karanikolos et al., 2013; 2016; Kentikelenis et al., 2015a; Maresso et al., 2015; Mladovsky et al., 2012; Ruckert and Labonté, 2012b; Thomson et al., 2015); this ground is covered here only as it relates to policies introduced through IFI conditionalities.

\section{[Figure 1 here]}

\subsection{Direct effects on health systems}

Structural adjustment policies directly affect health systems in several ways. First, their stabilization component (most importantly, austerity measures) may stipulate changes to the financing structure of healthcare. Governments may be required to reduce public health expenditure, or to replace public with private—often, aid—financing (Mladovsky et al., 2012; Reeves et al., 2013; Sridhar and Woods, 2010; Stubbs et al., 2016b). Sharp changes in public health spending patterns can impact the volume and quality of services provided (e.g., number of health facilities) (McCoy et al., 2005; Stuckler and Basu, 2009). Studies on the effects of structural 
adjustment on social expenditures suggest that adjustment is associated with decreases in spending in low-income countries outside Sub-Saharan Africa and in democracies, and with increases in spending in Sub-Saharan African low-income countries and autocracies (Kentikelenis et al., 2015b; Nooruddin and Simmons, 2006). Further, IFI programs in Latin America have been linked to decreases in public expenditures on social policy and welfare and social security, but increases in health spending (Noy, 2011).

Second (and related to austerity), the public sector healthcare workforce is also affected via redundancies, hiring freezes or wage cuts (Kentikelenis et al., 2014b; Lloyd and Weissman, 2002; Maresso et al., 2015; Marphatia et al., 2007; McCoy et al., 2008; Rowden, 2009; Stubbs et al., 2016b; Stuckler and Basu, 2009). This process has been more explicit through reliance on 'wage bill ceilings'-mandated maxima of government spending on wages. These ceilings have been identified as key impediments to hiring or retaining health sector workers, and are linked to a medical 'brain drain' as healthcare workers migrate in search of better employment opportunities (Lefrançois, 2010; Marphatia, 2009; McColl, 2008; McCoy et al., 2008; Rowden, 2008). While reportedly discontinued (Gupta, 2015), recent evidence shows that wage bill limits are still incorporated into some IMF programs (Kentikelenis et al., 2016).

Third, revenue-raising and cost-cutting elements of structural adjustment programs have affected different dimensions of health coverage. One common such measure has been the introduction of user fees for access to healthcare and co-payments for medicines or services (Kentikelenis et al., 2014b; Mladovsky et al., 2012; Sen and Koivusalo, 1998; Thomson et al., 2015). The rationale for applying such fees was generating additional resources, improving efficiency, and increasing access (World Bank, 1987). Yet, they failed to live up to their promise (McIntyre et al., 2006), and have been linked to reduced access for the poor, high administration costs, and bureaucratic inefficiencies (Yates, 2009). In recent years, IFIs' policy consensus vis-à-vis low-income countries has moved away from reliance on user fees, yet addressing their lasting consequences on health will take prolonged and concerted efforts (Rowden, 2013). Even so, recent IFI-designed programs in Europe advocated the introduction or increase of user fees or co-payments (Maresso et al., 2015). In addition, healthcare coverage can be impacted by altering benefits packages or eligibility criteria for services (Thomson et al., 2015).

Fourth, deregulation can affect the public-private mix in health service provision, primarily by enhancing the private sector's role (Homedes and Ugalde, 2005). Opening markets for private providers can have a dual impact on health. Strata of the population able to afford private healthcare can gain access to a broader bundle of services (Loewenson, 1995). However, this may be coupled with the state rolling back public provision to a limited array of services for the poor (Sen and Koivusalo, 1998), or outsourcing it to non-governmental organizations (Pfeiffer, 2003; Pfeiffer and Chapman, 2010).

Fifth, structural adjustment programs have been linked to health system decentralization; i.e., transferring fiscal and operational responsibilities to the subnational level (Homedes and Ugalde, 2005; Kentikelenis et al., 2014b; Stubbs et al., 2016b). These policies can generate savings in the short-run, and aim to bring decision-making closer to local needs (Dillinger et al., 1999). However, they can also contribute to inadequate health system coordination and budget execution problems, as local authorities may lack technical capacities and or divert funds to alternative uses (Djibuti et al., 2007).

Finally, to counter some adverse effects of structural adjustment on health systems, the IMF programs increasingly incorporate priority spending floors, stipulating minimum expenditures on - primarily - health and education (Gupta et al., 2000). Yet, these safeguards have not been adequately incorporated into the design of adjustment programs, and are accorded secondary importance in contrast to economic targets (Ruckert and Labonté, 2012a). Recent evidence shows that priority spending targets were observed about half the time, even though conditions on fiscal consolidation were almost always met (Kentikelenis et al., 2014b; 2016). 
As a result of these effects on health systems, non-state actors have often sought to fill the gaps in healthcare provision left by retreating state services. In particular, international or nongovernmental organizations often step in to offer health services to vulnerable groups - sometimes bypassing governments (Kentikelenis and Shriwise, 2016; Sridhar and Woods, 2010). Even though some evidence points to improved health outcomes following these interventions (J. M. Shandra et al., 2010), they have been linked to coordination problems, limited range and quality of services, prolonged weak state capabilities in health policy (Kentikelenis et al., 2014b; Ravindran, 2010; Sridhar and Woods, 2010).

\subsection{Indirect effects on health systems}

Notwithstanding these direct impacts of structural adjustment policies, health systems can also be indirectly affected via stabilization, liberalization, and privatization policies, as well as possible increased aid flows due to the presence of an IMF or World Bank program. First, in addition to fiscal consolidation reviewed above, a key element of stabilization policies has been currency devaluation, advocated by IFIs to improve the external competitiveness of countries. However, raised import prices due to a weak currency impact health systems by impeding access to imported medicines and medical equipment (Breman and Shelton, 2006).

Second, trade and capital account liberalization policies can affect health systems through multiple channels. The removal of tariffs and customs reduces trade tax revenues in the short-run (Baunsgaard and Keen, 2010), which — unless replaced by other revenues - can undermine the fiscal basis of health policy. Moreover, liberalization measures make economies more vulnerable to global economic fluctuations, hamper the development of infant industries, and contribute to external dependence (Kanji et al., 1991). These policies can impede a government's ability to develop and stably finance health systems. However, if the economic benefits of openness materialize in the medium-term, they can stimulate economic activity, thereby boosting public revenues that could be invested in the health system.

Third, the privatization component of structural adjustment affects numerous areas of state activities (in addition to health systems, reviewed above): state-owned enterprises and natural resources have been key targets (Bakker, 2003; Spronk and Webber, 2007). These policies are designed to raise funds for cash-strapped governments; however, in the medium- and long-run, states lose reliable public revenue sources, which could have been used as fiscal foundations for health policy (L. P. King et al., 2009; Peabody, 1996). Further, some state-owned enterprises also provide health coverage to employees, and-post-privatization - these benefits may be withdrawn and the (former) employees can lose access to healthcare (Stuckler and Basu, 2013; Stuckler et al., 2009).

Finally, the adverse consequences of structural adjustment on health systems-especially, public financing of health policy-could potentially be offset by increased aid flows and donor interventions (Clements et al., 2013). The 'fungibility' of health expenditures has been the focus of recent academic attention, with studies finding evidence of aid substituting - rather than complementing-government spending on health (Lu et al., 2010; Stuckler et al., 2010b). The presence of IFI programs has a catalytic effect on some types of aid flows (e.g., budget support and debt relief), but this relationship does not hold for health aid (Stubbs et al., 2016a).

\subsection{Effects on social determinants of health}

Beyond their effects on health systems, structural adjustment policies can have a profound impact on health outcomes by reshaping their 'social determinants' (Labonté and Schrecker, 2007; Marmot, 2006; Schrecker and Bambra, 2015). The term broadly refers to a complex and interlocking web of macro-level factors - 'the conditions in which people are born, grow, live, work, and age' (WHO, 2013, p. 6) - that affect population health. A landmark report 
commissioned by the World Health Organization broadly clustered these determinants under ten key themes: the social gradient, stress, early life, social exclusion, work, unemployment, social support, addiction, food, and transport (Wilkinson and Marmot, 2003). These categories are not mutually exclusive, but interact in multiple ways (Labonté and Schrecker, 2007); for example, the social gradient in health is affected by employment conditions or unemployment, and social exclusion can be affected by addiction or inadequate access to social support.

The links between structural adjustment and many of these social determinants of health have been underexplored in the relevant literature, partly due to methodological challenges like confounding and measurement problems (Bobak and Marmot, 2009). Table 1 synthesizes available evidence by matching the possible consequences of the dimensions of structural adjustment (stabilization, liberalization, deregulation and privatization) with the broad clusters of social determinants of health noted above. In doing so, the Table is indicative rather than exhaustive, as many of the expected effects on social determinants interact in complex ways and a range of unanticipated consequences may also emerge.

\section{[Table 1 here]}

These factors are key drivers of health outcomes, and can operate in ways that compound the health effects of structural adjustment policies; for instance, unemployment induced by mass privatizations coupled with the withdrawal of social support services due to austerity measures can lead to increased stress levels and addiction (Marmot and Bobak, 2000; Stuckler et al., 2009). Further, a temporal dimension is required for fully appreciating the health effects of structural adjustment policies: unlike their impact on health systems which may rapidly be reflected in outcomes, the health effects of changes in social determinants can take years-or decades-to manifest. For example, IMF-mandated deregulation policies fostering the spread of tobacco consumption (Gilmore et al., 2009) contribute to ill health after a long delay period.

Given the interlinkages between mechanisms and the extended time horizons involved, analyses of the health effects of structural adjustment should take a life-course approach. That is, policy reforms impact health over an individual's life-from birth to old age-in ways that merit special attention (see Marmot et al., 2012). Four key effects of structural adjustment on social determinants can have a large and lasting health impact that extends far beyond the duration of any given IFI program.

First, structural adjustment policies have been linked to dwindling incomes and increases in unemployment and poverty, with follow-on effects on inequality (Dreher, 2006; Oberdabernig, 2013; Vreeland, 2002). These - in turn —are root causes of a cascade of health problems over the life-course (Pickett and Wilkinson, 2015). Certain aspects of IFI reform programs can compound these effects. For example, the privatization of health services can result in reduced affordability, and-thus-long-term unmet medical needs or catastrophic household health expenditure (McIntyre et al., 2006). Similarly, a shift to regressive forms of taxation can reduce poor households' incomes (Stewart, 1991), and ability to afford healthcare or lead healthy lives. Finally, exchange rate liberalization can increase food prices, tied to deteriorations in children's nutritional status (Handa and D. King, 2003), with long-term implications for their development.

Second, education is a key social determinant of health, as it impacts health over the life course in two ways: it directly increases individuals' knowledge about health and how to access health services, and it improves social mobility opportunities which-in turn - feed into a host of other determinants of health (Cutler and Lleras-Muney, 2006; Jamison et al., 2013), yet structural adjustment policies have been shown to impede access to it, especially for women and the poor. For example, IMF and World Bank programs advocated the introduction of user fees for primary education or mandated education workforce reduction, thereby impeding educational attainment for children (Babb, 2005; Buchmann, 1996).

Third, structural adjustment has directly impacted the environment and environmental policies, 
including water and sanitation, agriculture and energy. For instance, IFI-mandated policies can result in environmental degradation, which in turn affects population health (Pacheco, 2006; C. L. Shandra et al., 2011; J. M. Shandra et al., 2008). Similarly, structural adjustment programs have favored large private concerns in agriculture and natural resources, rather than subsistence workers (Hilson and Potter, 2005; Pacheco, 2006). In addition to affecting the lives of these workers, agriculture commercialization alters the use of land in favor of cash crops, thereby making developing countries reliant on imports of basic foodstuffs and increasing the risk of being adversely impacted by global food price fluctuations (Lock et al., 2009). Further, structural adjustment policies can affect the degree, pace and mode of urbanization, which can set the stage for environmental degradation, disaster vulnerability and other health hazards (Hamza and Zetter, 1998). These structural adjustment-induced environment-related effects affect individuals' health over their entire life-course.

Finally, cultural norms, societal values, and social cohesion are directly impacted by structural adjustment, insofar as the latter erodes social cohesion and leads to a retreat to individualism (Hall and Lamont, 2013). These cultural and social-psychological effects are linked to a range of health outcomes. For instance, mass privatizations and employment protection liberalization increase psychosocial stress, which can have adverse mental health consequences and risky behavior (Antonakakis and Collins, 2014; Goulas and Zervoyianni, 2016; Kentikelenis, 2017; Stuckler et al., 2009; Stuckler and Basu, 2013). However, structural adjustment policies can also elicit cultural responses that contribute to 'resilience' in the face of rapid socioeconomic change (Hall and Lamont, 2013). For example, insofar as structural adjustment is linked to mass unemployment and roll-back of social policies, it can contribute to the emergence of societal responses that seek to integrate individuals into community initiatives or social movements, that —in turn-endow them with resources to reduce stress (Kentikelenis, 2017).

Overall, this section examined pathways through which structural adjustment affects health systems and outcomes. The synthesis of literature reveals multiple effects, but data limitations often mute a fine-grained appreciation of how these pathways interact with gender, class, and race. Nonetheless, the gendered consequences of structural adjustment have received persistent attention, and the main findings of past studies are summarized in Box 2.

[Box 2 here]

\section{Structural adjustment travels North: the case of Greece}

To test the conceptual framework's utility, the article examines Greece's experience with structural adjustment (2010-present), drawing on IFI reports and secondary literature. As noted above, countries have varied experiences with such programs, and the case of Greece is not necessarily 'representative.' Nonetheless, the country has attracted much recent academic attention (Karanikolos et al., 2016, p. 211), thereby serving as a 'strategic research ground' (Merton, 1987) on which to evaluate the framework's cogency.

The Greek economy and welfare state accumulated severe problems prior to the onset of the 2008/9 global financial crisis. After Greece revised the 2009 deficit projection from 3.7\% to $15.6 \%$ of GDP (Matsaganis, 2014, p. 112), a financial storm ensued and the government initiated talks with the international community about a possible 'economic adjustment program'; a program incorporating main precepts of structural adjustment, excluding currency devaluation due to Greece's Eurozone membership (see Greer (2014) for extended discussion). The first €110bn loan was agreed on in May 2010, committing the government to far-ranging austerity measures and structural reforms designed by the IMF, the European Central Bank, and the European Commission (collectively known as the Troika). The second and third bailouts were agreed upon in 2012 and 2015, and provided additional funds in exchange for further policy changes. The Greek welfare state-inequitable even pre-crisis (Kentikelenis and Papanicolas, 2012; Matsaganis, 2011) _ 
became a key focus of Troika-mandated reforms.

Building on the framework presented above, Greece's structural adjustment reforms impacted the health system and outcomes through three pathways. Direct targeting of the health system was common among Troika-mandated reforms. A key condition of the bailout was capping public health expenditure to 6\% of GDP (IMF, 2010). This target was met through cuts to hospital operating costs, social health insurance funds, and public health services (IMF, 2011a), as well as through a reduction of benefits offered by social security funds (IMF, 2011b). In addition, public pharmaceutical expenditures were also targeted; a necessary measure due to high rates of branded drug prescription (IMF, 2010). In parallel to cost-cutting measures, revenue-raising reforms also formed a key part of Greece's adjustment program: user fees were increased or introduced, and copayments for medicines were increased (IMF, 2010).

Indirect effects of structural adjustment policies on Greece's health system were primarily linked to stringent austerity measures applied across the public sector, limiting the number and remuneration of public employees and capping new recruitment (IMF, 2012). Further, several reforms impacted public revenues, as additional taxes and levies were introduced to cover budgetary shortfalls (IMF, 2012; 2011b; 2010). These waves of revenue-generating measures resulted in depressed economic activity, thereby undermining revenue collection (Stiglitz, 2016). In addition, the structural adjustment-induced economic contraction eroded the health system's fiscal foundations, as revenues of social insurance funds declined by 20.5\% between 2008 and 2013 (C. Economou et al., 2014).

Both direct and indirect impacts of structural adjustment on the Greek health system had follow-on effects on population health, with early findings reporting worsening health trends (Kentikelenis et al., 2011; Stuckler and Basu, 2013). Recent studies have found increases in unmet medical need, linked to the inability to afford care or reach health services due to distance or scarcity of transportation (Kentikelenis et al., 2014a; Zavras et al., 2016). Prohibitive healthcare costs primarily affected low-income individuals (Karanikolos and Kentikelenis, 2016). Some essential reforms - like curbing pharmaceutical expenditure-were linked to drug shortages (Karamanoli, 2015). Further, the health of some vulnerable groups markedly deteriorated due to structural adjustment-linked policies. Most notably, inadequate preventative services-rolled-back due to austerity measures-and homelessness contributed to an HIV outbreak in Athens, primarily concentrated among injecting drug users (Kentikelenis et al., 2014a; 2015a; Stuckler and Basu, 2013).

To counter some of these adverse effects, the IMF promoted social amelioration measures, including health vouchers and universal healthcare provision for those uninsured (IMF, 2015). Yet, evidence on these policies suggests insufficient implementation and administrative hurdles for beneficiaries (C. Economou et al., 2014; Kentikelenis, 2015). Health coverage for the uninsured was introduced in April 2016; six years after the onset of structural adjustment in Greece.

Finally, Troika-mandated economic and institutional reforms profoundly impacted the social determinants of health in Greece. Liberalized labor markets, reduced labor costs and excessive austerity measures contributed to a rapid deterioration in economic conditions, having a toll on individuals and households (Matsaganis and Leventi, 2014). Mental health was first to be affected by austerity and structural reforms, with increased prevalence of depression and suicidality (M. Economou et al., 2016; 2012; 2013; 2011; Kentikelenis et al., 2012) and a rise in suicides (Antonakakis and Collins, 2014; Branas et al., 2015). Further, increases in homelessness, child poverty, food insecurity, drug use and precarious work have been linked to a range of adverse health effects (Kentikelenis et al., 2014a; Stuckler and Basu, 2013). The likely long-term health implications of these changes in the social determinants of health are even more devastating, but several years will pass before they can be systematically assessed.

This brief overview has shown how the effects of structural adjustment on health can be organized 
within a unifying framework that illuminates different mechanisms at work. As the empirical evidence suggests, the pathways linking structural adjustment and health interact in multiple ways. For example, mental health being impacted by deteriorating economic conditions and the retrenchment of welfare services, as well as changing social norms (Kentikelenis, 2017).

\section{Discussion and conclusions}

This article examined how structural adjustment programs affect health systems and outcomes. Drawing on a literature review, the article presented a conceptual framework elaborating on the main pathways, and demonstrated its utility by populating it with empirical evidence from Greece's experience. While episodes of economic crises and structural adjustment often coincide, the framework shows that structural adjustment policies affect health in ways that compound, ameliorate or are unrelated to the effects of economic crises. Tracing these exact links is a necessary component for evaluating the health effects of IFI programs, and-more generallyneoliberalism.

Before discussing the findings, three limitations are noteworthy. First, the pathways identified are relevant to countries' experiences with structural adjustment, yet they need not all be present at all times. This depends on the exact policy content of IFI programs, and future research can offer evidence of links between specific policies and outcomes. Second, while the article discussed policy reform lending activities of the IMF and the World Bank, these organizations have multifaceted operations that impact health in ways beyond this study's scope. For example, the World Bank supports health sector-related projects (Brown et al., 2013), and both organizations create norms about appropriate health policy. Finally, lending activities of other IFIs - such as the African Development Bank—have also been shown to affect health (Coburn et al., 2015a; 2015b), but in-depth assessments of their operations remain scarce.

The pathways examined above point to some contradictory links. In the short run, structural adjustment can be linked to adverse effects on health, due to individual-level factors (unemployment, economic hardship, psychosocial distress) and institutional factors (availability and quality of healthcare services, health system operating principles). Even so, individuals' socioeconomic status is a key mediating factor. For those having stable formal-sector employment or high incomes, structural adjustment policies may be linked to higher cost of care, but access to health services is seldom at risk. In some cases, access may improve as the private healthcare sector expands. In contrast, for individuals of lower socio-economic status, structural adjustment policies may translate into the removal of hitherto available healthcare services, and reliance on expensive services provided by the private sector. Social protection policies-if appropriately designed-may ameliorate these adverse impacts.

The medium- and long-term effects of structural adjustment programs are equally important, yet difficult to accurately estimate and have received little attention in the literature. Policies like trade liberalization may eventually create new employment opportunities and boost economic performance, but other structural adjustment reforms - like mass privatization-may contribute to long-term unemployment resulting in ill health. In relation to health systems, the underfunding, privatization or decentralization of healthcare may weaken public health system capacity, which requires prolonged investment to be overcome. However, some policies-like the reliance on user fees-can be easily reversed, especially when governments cooperate with domestic and international partners to design alternative policy arrangements: user-fee removal in Uganda quickly translated in increases in health service utilization, especially by the poor (Yates, 2009).

The conceptual framework presented here can aid ex ante assessments of the potential health effects of structural adjustment programs. Existing health impact assessment frameworks offer sophisticated tools for analyses of well-defined policy interventions; for example, the construction of mines or dams (see WHO, 2016). However, structural adjustment programs relate to further 
upstream determinants of policymaking: they set fiscal parameters for all public policies, affect market-state relations, and determine the mode of countries' integration into the global economic system. This article presented a unified framework of analysis within which the multiple components of IFI policy reform programs are incorporated. This framework can be employed to guide policy design that is sensitive to public health.

Despite structural adjustment programs, options remain for sheltering and strengthening health policy. Some low-income countries have managed to attenuate adverse effects of structural adjustment on their health systems and improve coverage through collaborations with international donors, national-level planning, and appropriate tailoring to health needs (Meessen et al., 2006). Middle-income countries have self-insured against reliance on IFIs, thereby having fiscal space to spend counter-cyclically (Bárcena, 2012).

The broader issue in evaluating the health effects of structural adjustment concerns the use of appropriate counterfactuals (Schrecker, 2016). In other words, what benchmark should analysts use to judge these effects? A common argument by IFIs and sympathetic observers is that -in the absence of their structural adjustment programs - health in borrowing countries would have deteriorated. This conjecture is indeed plausible: countries implementing structural adjustment programs are commonly in dire economic conditions, and a possible default could have devastating social consequences (partly the reason why countries are generally reluctant to follow this route). Consequently, the 'no structural adjustment' counterfactual is likely to reflect favorably on IFI activities. Yet, it is also profoundly unambitious, as it assumes that no alternative policy responses are available; that is, responses that would put economic reforms on equal footing with the protection of human and social welfare.

Alternative policy trajectories exist, and have now been codified in the United Nations' Sustainable Development Goals: they include improving health for all by ensuring universal health coverage and strong public healthcare systems. IFIs have resources and expertise available to help countries in attaining these goals, and their lending programs should embed health impact assessments. Three decades ago, the United Nations $(1988$, p. 5) declared that the ultimate test for IFI programs was 'whether they will improve the human condition from their inception or, on the contrary, worsen it.' This benchmark remains as relevant today as it was then. 


\section{References}

Antonakakis, N., Collins, A., 2014. The impact of fiscal austerity on suicide: On the empirics of a modern Greek tragedy. Social Science \& Medicine 112, 39-50. doi:10.1016/j.socscimed.2014.04.019

Assaad, R., Arntz, M., 2005. Constrained Geographical Mobility and Gendered Labor Market Outcomes Under Structural Adjustment: Evidence from Egypt. World Development 33, 431454. doi:10.1016/j.worlddev.2004.08.007

Babb, S.L., 2009. Behind the Development Banks: Washington Politics, World Poverty, and the Wealth of Nations. University of Chicago Press, Chicago.

Babb, S.L., 2005. The Social Consequences of Structural Adjustment: Recent Evidence and Current Debates. Annual Review of Sociology 31, 199-222. doi:10.1146/annurev.soc.31.041304.122258

Babb, S.L., Carruthers, B.G., 2008. Conditionality: Forms, Function, and History. Annu. Rev. Law. Soc. Sci. 4, 13-29. doi:10.1146/annurev.lawsocsci.4.110707.172254

Babb, S.L., Kentikelenis, A.E., 2017. International Financial Institutions as Agents of Neoliberalism, in: Cahill, D., Cooper, M., Konings, M. (Eds.), The SAGE Handbook of Neoliberalism. SAGE Publications, Thousand Oaks.

Bakker, K., 2003. Archipelagos and networks: urbanization and water privatization in the South. The Geographical Journal 169, 328-341. doi:10.1111/j.0016-7398.2003.00097.x

Baunsgaard, T., Keen, M., 2010. Tax revenue and (or?) trade liberalization. Journal of Public Economics 94, 563-577. doi:10.1016/j.jpubeco.2009.11.007

Bárcena, A., 2012. Growing Out of Poverty. Finance and Development 49, 44-45.

Bobak, M., Marmot, M.G., 2009. Societal transition and health. The Lancet 373, 360-362. doi:10.1016/S0140-6736(09)60043-X

Branas, C.C., Kastanaki, A.E., Michalodimitrakis, M., Tzougas, J., Kranioti, E.F., Theodorakis, P.N., Carr, B.G., Wiebe, D.J., 2015. The impact of economic austerity and prosperity events on suicide in Greece: a 30-year interrupted time-series analysis. BMJ Open 5, e005619. doi:10.1136/bmjopen-2014-005619

Breman, A., Shelton, C., 2006. Structural Adjustment Programs and Health, in: Kawachi, I., Wamala, S. (Eds.), Globalization and Health. Oxford University Press, Oxford.

Brown, S.S., Sen, K., Decoster, K., 2013. The health systems funding platform and World Bank legacy: the gap between rhetoric and reality. Global Health 9, 9. doi:10.1016/j.jdeveco.2008.06.014

Buchmann, C., 1996. The Debt Crisis, Structural Adjustment and Women's Education. International Journal of Comparative Sociology 37, 5-30. doi:10.1163/002071596X00208

Çağatay, N., Özler, Ş., 1995. Feminization of the Labor Force: The Effects of Long- Term Development and Structural Adjustment. World Development 23, 1883-1894. doi:10.1016/0305-750X(95)00086-R

Clements, B., Gupta, S., Nozaki, M., 2013. What happens to social spending in IMF-supported programmes? Applied Economics 45, 4022-4033. doi:10.1080/00036846.2012.744136

Coburn, C., Restivo, M., Shandra, J.M., 2015a. The African Development Bank and infant mortality: A cross-national analysis of structural adjustment and investment lending from 1990 to 2006. International Journal of Comparative Sociology 56, 275-296. doi:10.1177/0020715215610799

Coburn, C., Restivo, M., Shandra, J.M., 2015b. The African Development Bank and women's health: A cross-national analysis of structural adjustment and maternal mortality. Social Science Research 51, 307-321. doi:10.1016/j.ssresearch.2014.09.007

Cornia, G.A., Jolly, R., Stewart, F. (Eds.), 1987. Adjustment with a Human Face: Volume I: Protecting the Vulnerable and Promoting Growth. Oxford University Press, Oxford.

Cutler, D., Lleras-Muney, A., 2006. Education and Health: Evaluating Theories and Evidence. National Bureau of Economic Research Working Paper 12352. doi:10.3386/w12352

De Vogli, R., 2011. Neoliberal globalisation and health in a time of economic crisis. Soc Theory 
Health 9, 311-325. doi:10.1057/sth.2011.16

De Vogli, R., Birbeck, G.L., 2005. Potential impact of adjustment policies on vulnerability of women and children to HIV/AIDS in sub-Saharan Africa. J Health Popul Nutr 23, 105-120.

Dillinger, W., Gutman, J., Burki, S.J., Rojas, F., Perry, G., Griffin, C., Webb, S., Winkler, D., 1999. Beyond the Center: Decentralizing the State. World Bank, Washington, DC.

Djibuti, M., Rukhadze, N., Hotchkiss, D.R., Eisele, T.P., Silvestre, E.A., 2007. Health systems barriers to effective use of infectious disease surveillance data in the context of decentralization in Georgia: A qualitative study. Health policy 83, 323-331. doi:10.1016/j.healthpol.2007.02.009

Dreher, A., 2006. IMF and economic growth: The effects of programs, loans, and compliance with conditionality. World Development 34, 769-788. doi:10.1016/j.worlddev.2005.11.002

Economou, C., Kaitelidou, D., Kentikelenis, A.E., Sissouras, A., Maresso, A., 2014. The impact of the financial crisis on health and the health system in Greece, in: Maresso, A., et al. (Eds.), Economic Crisis, Health Systems and Health in Europe: Country Experience. WHO/European Observatory on Health Systems and Policies, Copenhagen, pp. 103-142.

Economou, M., Angelopoulos, E., Peppou, L.E., Souliotis, K., Tzavara, C., Kontoangelos, K., Madianos, M., Stefanis, C., 2016. Enduring financial crisis in Greece: prevalence and correlates of major depression and suicidality. Soc Psychiatry Psychiatr Epidemiol 51, 10151024. doi:10.1007/s00127-016-1238-z

Economou, M., Madianos, M., Peppou, L.E., Patelakis, A., Stefanis, C.N., 2012. Major depression in the Era of economic crisis: A replication of a cross-sectional study across Greece. Journal of Affective Disorders 145, 308-314. doi:10.1016/j.jad.2012.08.008

Economou, M., Madianos, M., Peppou, L.E., Theleritis, C., Patelakis, A., Stefanis, C.N., 2013. Suicidal ideation and reported suicide attempts in Greece during the economic crisis. World Psychiatry 12, 53-60. doi:10.1002/wps.20016

Economou, M., Madianos, M., Theleritis, C., Peppou, L.E., Stefanis, C.N., 2011. Increased suicidality amid economic crisis in Greece. The Lancet 378, 1459. doi:10.1016/S01406736(11)61638-3

Gilmore, A., Fooks, G., McKee, M., 2009. The International Monetary Fund and Tobacco: A Product like Any Other? International Journal of Health Services 39, 789-793. doi:10.2190/HS.39.4.1

Goulas, E., Zervoyianni, A., 2016. IMF-lending programs and suicide mortality. Social Science \& Medicine 153, 44-53. doi:10.1016/j.socscimed.2016.01.045

Greer, S.L., 2014. Structural adjustment comes to Europe: Lessons for the Eurozone from the conditionality debates. Global Social Policy 14, 51-71. doi:10.1177/1468018113511473

Gupta, S., 2015. Response to "The International Monetary Fund and the Ebola outbreak.” The Lancet Global Health 3, e78. doi:10.1016/S2214-109X(14)70345-6

Gupta, S., Dicks-Mireaux, L., Khemani, R., McDonald, C., Verhoeven, M., 2000. Social Issues in IMF-Supported Programs. IMF Occasional Papers 191.

Hall, P.A., Lamont, M. (Eds.), 2013. Social Resilience in the Neo-Liberal Era. Cambridge University Press, Cambridge.

Hall, P.A., Lamont, M. (Eds.), 2009. Successful Societies: How Institutions and Culture Affect Health. Cambridge University Press, Cambridge.

Hamza, M., Zetter, R., 1998. Structural adjustment, urban systems, and disaster vulnerability in developing countries. Cities 15, 291-299. doi:10.1016/S0264-2751(98)00020-1

Handa, S., King, D., 2003. Adjustment with a Human Face? Evidence from Jamaica. Economic Crises, Natural Disasters, and Poverty 31, 1125-1145. doi:10.1016/S0305-750X(03)00063-9

Hilson, G., Potter, C., 2005. Structural Adjustment and Subsistence Industry: Artisanal Gold Mining in Ghana. Development and Change 36, 103-131. doi:10.1111/j.0012155X.2005.00404.X

Homedes, N., Ugalde, A., 2005. Why neoliberal health reforms have failed in Latin America. Health policy 71, 83-96. doi:10.1016/j.healthpol.2004.01.011

IMF, 2015. Factsheet: Protecting the Most Vulnerable under IMF-supported Programs [WWW 
Document]. International Monetary Fund. URL

https://www.imf.org/external/np/exr/facts/protect.htm (accessed 4.21.15).

IMF, 2014. Transcript of the International Monetary and Financial Committee (IMFC) Press

Briefing [WWW Document]. International Monetary Fund. URL

https://www.imf.org/external/np/tr/2014/tr041214b.htm (accessed 4.21.15).

IMF, 2012. Greece: Letter of Intent, Memorandum of Economic and Financial Policies, and

Technical Memorandum of Understanding (December 21). International Monetary Fund, Washington, DC.

IMF, 2011a. Greece: Fifth Review Under the Stand-By Arrangement (No. 11/351). IMF, Washington DC.

IMF, 2011b. Greece: Letter of Intent, Memorandum of Economic and Financial Policies, and Technical Memorandum of Understanding, International Monetary Fund. Washington DC.

IMF, 2010. Greece: Letter of Intent, Memorandum of Economic and Financial Policies, and Technical Memorandum of Understanding (December 8). International Monetary Fund, Washington, DC.

IMF, 2009. Creating Policy Space - Responsive Design and Streamlined Conditionality in Recent Low-Income Country Programs. International Monetary Fund, Washington, DC.

Jamison, D.T., Summers, L.H., et al., 2013. Global health 2035: a world converging within a generation. The Lancet 382, 1898-1955. doi:10.1016/S0140-6736(13)62105-4

Kanji, N., Kanji, N., Manji, F., 1991. From development to sustained crisis: structural adjustment, equity and health. Social Science \& Medicine 33, 985-993. doi:10.1016/0277-9536(91)90003$\mathrm{U}$

Karamanoli, E., 2015. 5 years of austerity takes its toll on Greek health care. The Lancet 386, 2239-2240. doi:10.1016/S0140-6736(15)01163-0

Karanikolos, M., Heino, P., McKee, M., Stuckler, D., Legido-Quigley, H., 2016. Effects of the Global Financial Crisis on Health in High-Income Oecd Countries: A Narrative Review. International Journal of Health Services 46, 208-240. doi:10.1177/0020731416637160

Karanikolos, M., Kentikelenis, A.E., 2016. Health inequalities after austerity in Greece. Int J Equity Health 15, 1-3. doi:10.1186/s12939-016-0374-0

Karanikolos, M., Mladovsky, P., Cylus, J., Thomson, S., Basu, S., Stuckler, D., Mackenbach, J.P., McKee, M., 2013. Financial crisis, austerity, and health in Europe. The Lancet 381, 13231331. doi:10.1016/s0140-6736(13)60102-6

Kentikelenis, A.E., 2017. The Social Aftermath of Economic Disaster: Karl Polanyi, Countermovements in Action, and the Greek Crisis. Mimeo, University of Oxford.

Kentikelenis, A.E., 2015. Bailouts, austerity and the erosion of health coverage in Southern Europe and Ireland. The European Journal of Public Health 25, 365-366. doi:10.1093/eurpub/ckv055

Kentikelenis, A.E., Karanikolos, M., Papanicolas, I., Basu, S., McKee, M., Stuckler, D., 2012. Effects of Greek economic crisis on health are real. BMJ 345, e8602-e8602. doi:10.1136/bmj.e8602

Kentikelenis, A.E., Karanikolos, M., Papanicolas, I., Basu, S., McKee, M., Stuckler, D., 2011. Health effects of financial crisis: omens of a Greek tragedy. The Lancet 378, 1457-1458. doi:10.1016/S0140-6736(11)61556-0

Kentikelenis, A.E., Karanikolos, M., Reeves, A., McKee, M., Stuckler, D., 2014a. Greece's health crisis: from austerity to denialism. The Lancet 383, 748-753. doi:10.1016/S01406736(13)62291-6

Kentikelenis, A.E., Karanikolos, M., Williams, G., Mladovsky, P., King, L.P., Pharris, A., Suk, J.E., Hatzakis, A., McKee, M., Noori, T., Stuckler, D., 2015a. How do economic crises affect migrants' risk of infectious disease? A systematic-narrative review. The European Journal of Public Health 25, 937-944. doi:10.1093/eurpub/ckv151

Kentikelenis, A.E., King, L.P., McKee, M., Stuckler, D., 2014b. The International Monetary Fund and the Ebola outbreak. The Lancet Global Health 3, e69-e70. doi:10.1016/S2214109X(14)70377-8

Kentikelenis, A.E., Papanicolas, I., 2012. Economic crisis, austerity and the Greek public health 
system. The European Journal of Public Health 22, 4-5. doi:10.1093/eurpub/ckr190

Kentikelenis, A.E., Shriwise, A., 2016. International organizations and migrant health in Europe. Public Health Reviews 37, 1-20. doi:10.1186/s40985-016-0033-4

Kentikelenis, A.E., Stubbs, T.H., King, L.P., 2016. IMF conditionality and development policy space, 1985-2014. Review of International Political Economy 23, 543-582. doi:10.1080/09692290.2016.1174953

Kentikelenis, A.E., Stubbs, T.H., King, L.P., 2015b. Structural adjustment and public spending on health: Evidence from IMF programs in low-income countries. Social Science \& Medicine 126, 169-176. doi:10.1016/j.socscimed.2014.12.027

King, L.P., Hamm, P., Stuckler, D., 2009. Rapid Large-Scale Privatization and Death Rates in ExCommunist Countries: An Analysis of Stress-Related and Health System Mechanisms. International Journal of Health Services 39, 461-489. doi:10.2190/HS.39.3.c

Labonté, R., Schrecker, T., 2007. Globalization and social determinants of health: Introduction and methodological background. Global Health 3, 1-10. doi:10.1186/1744-8603-3-5

Labonté, R., Schrecker, T., Packer, C., Runnels, V. (Eds.), 2009. Globalization and Health: Pathways, Evidence and Policy. Routledge, London.

Labonté, R., Stuckler, D., 2016. The rise of neoliberalism: how bad economics imperils health and what to do about it. J Epidemiol Community Health 70, 312-319. doi:10.1136/jech-2015206295

Lefrançois, F., 2010. The IMF, the Global Crisis \& Human Resources for Health: Still Constraining Policy Space. UK Consortium on AIDS \& International Development and Action for Global Health UK, London.

Lloyd, V., Weissman, R., 2002. How International Monetary Fund and World Bank Policies Undermine Labor Power and Rights. International Journal of Health Services 32, 433-442. doi:10.2190/WMC9-0WWJ-8QWR-UFPC

Lock, K., Stuckler, D., Charlesworth, K., McKee, M., 2009. Potential causes and health effects of rising global food prices. BMJ 339, b2403-b2403. doi:10.1136/bmj.b2403

Loewenson, R., 1995. Structural Adjustment and Health Policy in Africa. International Journal of Health Services 23, 717-730. doi:10.2190/WBQL-B4JP-K1PP-J7Y3

Lu, C., Schneider, M.T., Gubbins, P., Leach-Kemon, K., Jamison, D., Murray, C.J., 2010. Public financing of health in developing countries: a cross-national systematic analysis. The Lancet 375, 1375-1387. doi:10.1016/S0140-6736(10)60233-4

Maresso, A., Mladovsky, P., Thomson, S., Sagan, A., Karanikolos, M., Richardson, E., Cylus, J., Evetovits, T., Jowett, M., Figueras, J., Kluge, H., 2015. Economic crisis, health systems and health in Europe: Country experiences. Open University Press, Maidenhead.

Marmot, M.G., 2006. Health in an Unequal World. Royal College of Physicians, London.

Marmot, M.G., Allen, J., Bell, R., Bloomer, E., Goldblatt, P., 2012. WHO European review of social determinants of health and the health divide. The Lancet 380, 1011-1029. doi:10.1016/S0140-6736(12)61228-8

Marmot, M.G., Bobak, M., 2000. Psychosocial and Biological Mechanisms behind the Recent Mortality Crisis in Central and Eastern Europe, in: Cornia, G.A., Paniccià, R. (Eds.), The Mortality Crisis in Transitional Economies. Oxford University Press, Oxford, pp. 128-149.

Marmot, M.G., Wilkinson, R.G. (Eds.), 2006. Social determinants of health. Oxford University Press, Oxford.

Marphatia, A.A., 2009. The Adverse Effects of International Monetary Fund Programs on the Health and Education Workforce. International Journal of Health Services 40, 165-178. doi:10.2190/HS.40.1.j

Marphatia, A.A., Moussie, R., Ainger, A.-M., Archer, D., 2007. Confronting the Contradictions: The IMF, wage bill caps and the case for teachers. ActionAid International, London.

Matsaganis, M., 2014. The Catastrophic Greek Crisis. Current History 113, 110-116.

Matsaganis, M., 2011. The welfare state and the crisis: the case of Greece. Journal of European Social Policy 21, 501-512. doi:10.1177/0958928711418858

Matsaganis, M., Leventi, C., 2014. Poverty and Inequality during the Great Recession in Greece. 
Political Studies Review 12, 209-223. doi:10.1111/1478-9302.12050

Mays, N., Pope, C., Popay, J., 2005. Systematically reviewing qualitative and quantitative evidence to inform management and policy-making in the health field. Journal of Health Services Research \& Policy 10, 6-20. doi:10.1258/1355819054308576

McColl, K., 2008. Fighting the brain drain. BMJ 337, a1496. doi:10.1136/bmj.a1496

McCoy, D., Bennett, S., Witter, S., Pond, B., Arrow, K.J., Gow, J., Chand, S., Ensor, T., McPake, B., 2008. Salaries and incomes of health workers in sub-Saharan Africa. The Lancet 371, 675681. doi:10.1016/S0140-6736(08)60306-2

McCoy, D., Chopra, M., Loewenson, R., Aitken, J.-M., Ngulube, T., Muula, A., Ray, S., Kureyi, T., Ijumba, P., Rowson, M., 2005. Expanding Access to Antiretroviral Therapy in Sub-Saharan Africa: Avoiding the Pitfalls and Dangers, Capitalizing on the Opportunities. American Journal of Public Health 95, 18-22. doi:10.2105/AJPH.2004.040121

McIntyre, D., Thiede, M., Dahlgren, G., Whitehead, M., 2006. What are the economic consequences for households of illness and of paying for health care in low- and middleincome country contexts? Social Science \& Medicine 62, 858-865. doi:10.1016/j.socscimed.2005.07.001

Meessen, B., Van Damme, W., Tashobya, C.K., Tibouti, A., 2006. Poverty and user fees for public health care in low-income countries: lessons from Uganda and Cambodia. The Lancet 368, 2253-2257. doi:10.1016/S0140-6736(06)69899-1

Merton, R.K., 1987. Three Fragments from a Sociologist's Notebooks: Establishing the Phenomenon, Specified Ignorance, and Strategic Research Materials. Annual Review of Sociology 13, 1-28. doi:10.1146/annurev.so.13.080187.000245

Mladovsky, P., Srivastava, D., Cylus, J., Karanikolos, M., Evetovits, T., Thomson, S., McKee, M., 2012. Health policy responses to the financial crisis in Europe. WHO Policy Summary 5.

Mohindra, K.S., Labonté, R., Spitzer, D., 2011. The global financial crisis: whither women's health? Critical Public Health 21, 273-287. doi:10.1080/09581596.2010.539593

Nolte, E., Brand, A., Koupilová, I., McKee, M., 2000. Neonatal and postneonatal mortality in Germany since unification. Journal of Epidemiology \& Community Health 54, 84-90. doi:10.1136/jech.54.2.84

Nooruddin, I., Simmons, J., 2006. The Politics of Hard Choices: IMF Programs and Government Spending. Int. Org. 60, 1001-1033. doi:10.1017/S0020818306060334

Noy, S., 2011. New contexts, different patterns? A comparative analysis of social spending and government health expenditure in Latin America and the OECD. International Journal of Comparative Sociology 52, 215-244. doi:10.1177/0020715211408760

Oberdabernig, D.A., 2013. Revisiting the Effects of IMF Programs on Poverty and Inequality. World Development 46, 113-142. doi:10.1016/j.worlddev.2013.01.033

Ortiz, I., Chai, J., Cummins, M., 2011. Austerity Measures Threaten Children and Poor Households: Recent Evidence in Public Expenditures from 128 Developing Countries. UNICEF Social and Economic Policy Working Paper.

Pacheco, P., 2006. Agricultural expansion and deforestation in lowland Bolivia: the import substitution versus the structural adjustment model. Land Use Policy 23, 205-225. doi:10.1016/j.landusepol.2004.09.004

Pandolfelli, L.E., Shandra, J.M., Tyagi, J., 2014. The International Monetary Fund, Structural Adjustment, and Women's Health: a Cross-National Analysis of Maternal Mortality in SubSaharan Africa. Sociological Quarterly 55, 119-142. doi:10.1111/tsq.12046

Patel, M.S., Phillips, C.B., 2015. Health security and political and economic determinants of Ebola. The Lancet 386, 737-738. doi:10.1016/S0140-6736(15)61533-1

Peabody, J.W., 1996. Economic reform and health sector policy: Lessons from structural adjustment programs. Social Science \& Medicine 43, 823-835. doi:10.1016/02779536(96)00127-X

Pfeiffer, J., 2003. International NGOs and primary health care in Mozambique: the need for a new model of collaboration. Social Science \& Medicine 56, 725-738. doi:10.1016/s02779536(02)00068-0 
Pfeiffer, J., Chapman, R., 2010. Anthropological Perspectives on Structural Adjustment and Public Health. Annu. Rev. Anthropol. 39, 149-165. doi:10.1146/annurev.anthro.012809.105101

Pickett, K.E., Wilkinson, R.G., 2015. Income inequality and health: A causal review. Social Science \& Medicine 128, 316-326. doi:10.1016/j.socscimed.2014.12.031

Ravindran, T.S., 2010. Privatisation in reproductive health services in Pakistan: three case studies. Reproductive Health Matters 18, 13-24. doi:10.1016/S0968-8080(10)36536-0

Reeves, A., McKee, M., Basu, S., Stuckler, D., 2013. The political economy of austerity and healthcare: Cross-national analysis of expenditure changes in 27 European nations 1995-2011. Health policy 115, 1-8. doi:10.1016/j.healthpol.2013.11.008

Rowden, R., 2013. The ghosts of user fees past: Exploring accountability for victims of a 30-year economic policy mistake. Health and Human Rights 15. doi:10.1002/14651858.CD009094

Rowden, R., 2009. The deadly ideas of neoliberalism: how the IMF has undermined public health and the fight against AIDS. Zed Books, London.

Rowden, R., 2008. Blocking Progress: The IMF and HIV/AIDS. Global Social Policy 8, 19-24. doi:10.1177/14680181080080010106

Ruckert, A., Labonté, R., 2012a. The financial crisis and global health: the International Monetary Fund's (IMF) policy response. Health Promotion International 28, 357-366. doi:10.1093/heapro/das016

Ruckert, A., Labonté, R., 2012b. The global financial crisis and health equity: toward a conceptual framework. Critical Public Health 22, 267-279. doi:10.1080/09581596.2012.685053

Schrecker, T., 2016. Neoliberalism and Health: The Linkages and the Dangers. Sociology Compass 10, 952-971. doi:10.1111/soc4.12408

Schrecker, T., Bambra, C., 2015. How Politics Makes Us Sick: Neoliberal Epidemics. Palgrave Macmillan, Basingstoke.

Sen, K., Koivusalo, M., 1998. Health care reforms and developing countries-a critical overview. Int. J. Health Plann. Mgmt. 13, 199-215. doi:10.1002/(SICI)10991751(1998070)13:3<199::AID-HPM518>3.0.CO;2-1

Shandra, C.L., Shandra, J.M., London, B., 2011. World Bank Structural Adjustment, Water, and Sanitation: A Cross-National Analysis of Child Mortality in Sub-Saharan Africa. Organization \& Environment 24, 107-129. doi:10.1177/1086026611413931

Shandra, J.M., Shandra, C.L., London, B., 2010. Do Non-Governmental Organizations Impact Health? A Cross-National Analysis of Infant Mortality. International Journal of Comparative Sociology 51, 137-164. doi:10.1177/0020715209347066

Shandra, J.M., Shor, E., London, B., 2008. Debt, Structural Adjustment, and Organic Water Pollution: A Cross-National Analysis. Organization \& Environment 21, 38-55. doi:10.1177/1086026608314759

Sommer, J.M., Shandra, J.M., Restivo, M., Coburn, C., 2015. Water, Sanitation, and Health in SubSaharan Africa: A Cross-national Analysis of Maternal and Neo-natal Mortality. Human Ecology Review 22, 129-152.

Spronk, S., Webber, J.R., 2007. Struggles against Accumulation by Dispossession in Bolivia: The Political Economy of Natural Resource Contention. Latin American Perspectives 34, 31-47. doi:10.1177/0094582X06298748

Sridhar, D., Woods, N., 2010. Are there simple conclusions on how to channel health funding? The Lancet 375, 1326-1328. doi:10.1016/S0140-6736(10)60486-2

Stewart, F., 1991. The many faces of adjustment. World Development 19, 1847-1864. doi:10.1016/0305-750X(91)90029-H

Stiglitz, J.E., 2016. The Euro: How a Common Currency Threatens the Future of Europe. W.W. Norton \& Company, New York.

Stubbs, T.H., Kentikelenis, A.E., King, L.P., 2016a. Catalyzing Aid? The IMF and Donor Behavior in Aid Allocation. World Development 78, 511-528. doi:10.1016/j.worlddev.2015.10.010

Stubbs, T.H., Kentikelenis, A.E., Stuckler, D., McKee, M., King, L.P., 2016b. The impact of IMF conditionality on government health expenditure: A cross-national analysis of 16 West African nations. Social Science \& Medicine. doi:10.1016/j.socscimed.2016.12.016 
Stuckler, D., Basu, S., 2013. The Body Economic: Why Austerity Kills. Basic Books, New York.

Stuckler, D., Basu, S., 2009. The International Monetary Fund's Effects on Global Health: Before and After the 2008 Financial Crisis. International Journal of Health Services 39, 771-781. doi:10.2190/HS.39.4.j

Stuckler, D., Basu, S., Gilmore, A., Batniji, R., Ooms, G., Marphatia, A.A., Hammonds, R., McKee, M., 2010a. An Evaluation of the International Monetary Fund's Claims about Public Health. International Journal of Health Services 40, 327-332. doi:10.2190/HS.40.2.m

Stuckler, D., Basu, S., McKee, M., 2010b. International Monetary Fund and Aid Displacement. International Journal of Health Services 41, 67-76. doi:10.2190/HS.41.1.e

Stuckler, D., King, L.P., McKee, M., 2009. Mass privatisation and the post-communist mortality crisis: a cross-national analysis. The Lancet 373, 399-407. doi:10.1016/S0140-6736(09)600052

Summers, L.H., Pritchett, L.H., 1993. The Structural-Adjustment Debate. American Economic Review 83, 383-389.

Thomson, S., Figueras, J., Evetovits, T., Jowett, M., Mladovsky, P., Cylus, J., Karanikolos, M., Kluge, H., 2015. Economic crisis, health systems and health in Europe: Impact and implications for policy. Open University Press, Maidenhead.

United Nations, 1988. The Khartoum Declaration - International Conference of the Human Dimension of Africa's Economic Recovery and Development. United Nations, Addis Ababa.

Vreeland, J.R., 2002. The Effect of IMF Programs on Labor. World Development 30, 121-139. doi:10.1016/S0305-750X(01)00101-2

WHO, 2016. Examples of HIA [WWW Document]. URL http://www.who.int/hia/examples/en/ (accessed 8.29.16).

WHO, 2013. Review of social determinants and the health divide in the WHO European Region. World Health Organization Regional Office for Europe, Copenhagen.

Wilkinson, R.G., Marmot, M.G., 2003. Social Determinants of Health: The Solid Facts. World Health Organization, Copenhagen.

World Bank, 2016. Environmental and Social Framework [WWW Document]. URL https://consultations.worldbank.org/Data/hub/files/consultation-template/review-and-updateworld-bank-safeguard-

policies/en/materials/the_esf_clean_final_for_public_disclosure_post_board_august_4.pdf (accessed 8.18.16).

World Bank, 2009. Development Policy Lending Retrospective: Flexibility, Customization, and Results [WWW Document]. URL http://documents.worldbank.org/curated/en/2009/11/11516130/2009-development-policylending-retrospective-flexibility-customization-results (accessed 8.20.15).

World Bank, 1987. Financing health services in developing countries: an agenda for reform. The World Bank, Washington, DC.

Yates, R., 2009. Universal health care and the removal of user fees. The Lancet 373, 2078-2081. doi:10.1016/S0140-6736(09)60258-0

Zavras, D., Zavras, A.I., Kyriopoulos, I.-I., Kyriopoulos, J., 2016. Economic crisis, austerity and unmet healthcare needs: the case of Greece. BMC Health Services Research 2016 16:1 16, 1. doi:10.1186/s12913-016-1557-5 
Figure 1. Structural adjustment \& health: overview of mechanisms

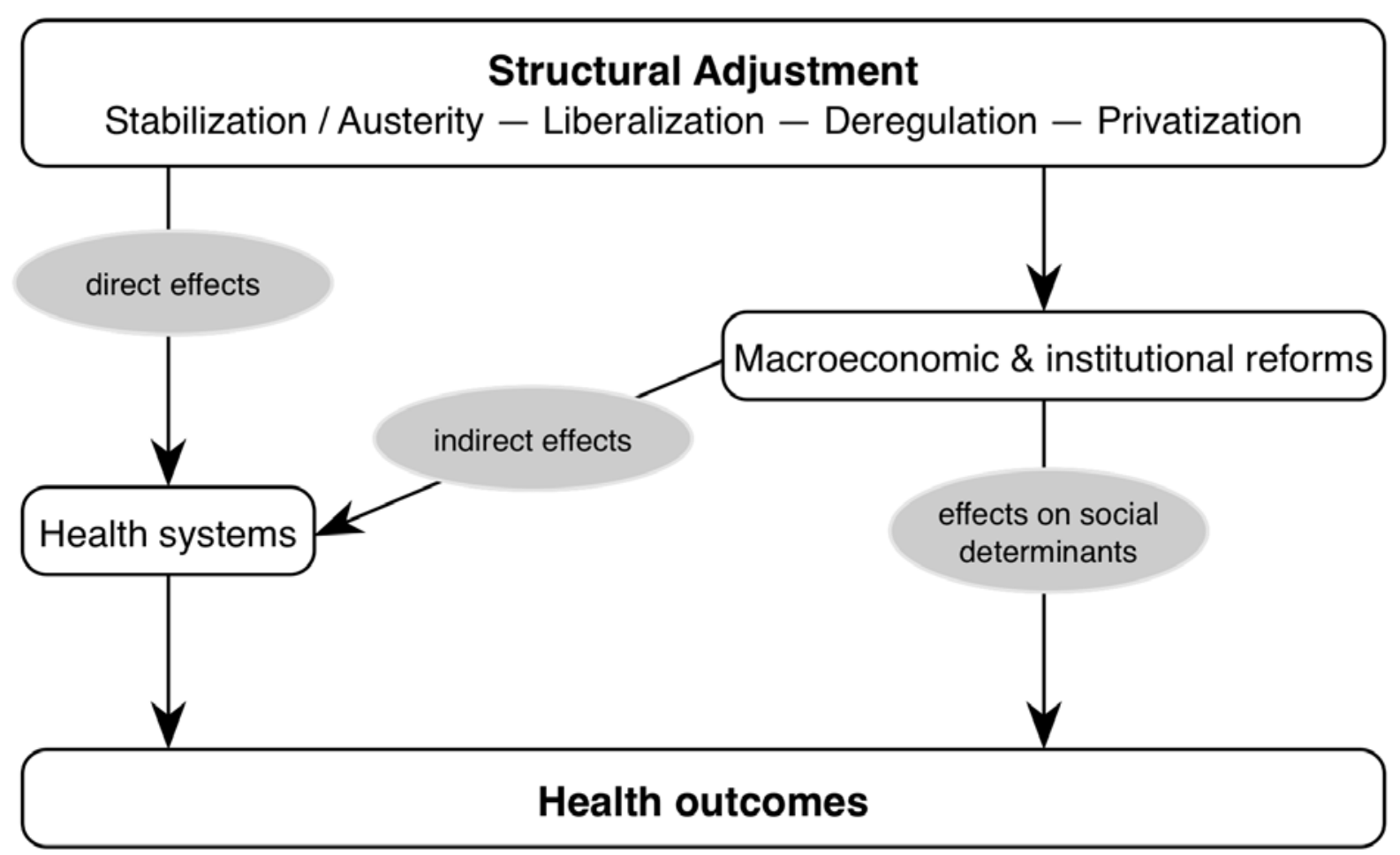

Source: Author. 
Table 1. Structural Adjustment and the Social Determinants of Health

\begin{tabular}{|c|c|c|}
\hline $\begin{array}{l}\text { Aspect of structural } \\
\text { adjustment }\end{array}$ & Possible consequences (positive or negative) & $\begin{array}{l}\text { Social } \\
\text { determinant } \\
\text { affected }\end{array}$ \\
\hline \multirow{11}{*}{$\begin{array}{l}\text { Stabilization / } \\
\text { Austerity }\end{array}$} & Increased inequality & \\
\hline & $\begin{array}{l}\text { Changes to availability and cost of housing } \\
\text { Reductions in inflation or hyperinflation } \\
\text { Reduction in the likelihood of currency crisis }\end{array}$ & Social gradient \\
\hline & $\begin{array}{l}\text { Reduction of available health services } \\
\text { Reductions in inflation or hyperinflation }\end{array}$ & Stress \\
\hline & $\begin{array}{l}\text { Inadequate access to nutrition or healthcare } \\
\text { Reduced availability of or access to education }\end{array}$ & Early life \\
\hline & Erosion of communities and social solidarities & Social exclusion \\
\hline & Precarious working conditions & Work \\
\hline & $\begin{array}{l}\text { Compounding of adverse economic effects of crises } \\
\text { (e.g., by misestimating appropriate degree of fiscal } \\
\text { consolidation) }\end{array}$ & Unemployment \\
\hline & $\begin{array}{l}\text { Limited public funds available for social policies } \\
\text { Increased cost of inputs (e.g., medicines) due to } \\
\text { devaluation }\end{array}$ & Social support \\
\hline & $\begin{array}{l}\text { Reduction in consumption of alcohol or tobacco due to } \\
\text { reduced incomes }\end{array}$ & Addiction \\
\hline & Increased cost of imported food due to devaluation & Food \\
\hline & $\begin{array}{l}\text { Decreased reliance on cars contributing to reduced } \\
\text { traffic accidents } \\
\text { Increased cost of travel to access healthcare due to } \\
\text { clinic closures }\end{array}$ & Transport \\
\hline \multirow[t]{9}{*}{$\begin{array}{l}\text { Trade \& Capital } \\
\text { account liberalization }\end{array}$} & $\begin{array}{l}\text { Increased inequality } \\
\text { Increased opportunities for skilled workers }\end{array}$ & Social gradient \\
\hline & Increased competition leading to job insecurity & Stress \\
\hline & Reductions in child labor & Early life \\
\hline & $\begin{array}{l}\text { Changing social norms (free-market economies favor } \\
\text { competition and individualistic traits rather than } \\
\text { community and social solidarity) }\end{array}$ & Social exclusion \\
\hline & $\begin{array}{l}\text { Wage reductions to secure competitiveness } \\
\text { Increased opportunities for skilled workers }\end{array}$ & Work \\
\hline & Increased exposure to global economic fluctuations & Unemployment \\
\hline & $\begin{array}{l}\text { Reduced trade-related taxes available for social } \\
\text { policies }\end{array}$ & Social support \\
\hline & Increased availability of tobacco & Addiction \\
\hline & $\begin{array}{l}\text { Increased exposure to food price fluctuations } \\
\text { Increased availability of unhealthy food }\end{array}$ & Food \\
\hline \multirow{6}{*}{$\begin{array}{l}\text { Economic } \\
\text { deregulation }\end{array}$} & Increased inequality & Social gradient \\
\hline & $\begin{array}{l}\text { Work flexibilization } \\
\text { Changes to housing laws and regulations that weaken } \\
\text { tenant protection }\end{array}$ & Stress \\
\hline & $\begin{array}{l}\text { Changes to housing laws and regulations that can } \\
\text { affect dwellings' availability, affordability and quality } \\
\text { for families }\end{array}$ & Early life \\
\hline & $\begin{array}{l}\text { Changing social norms (free-market economies favor } \\
\text { competition and individualistic traits rather than } \\
\text { community and social solidarity) }\end{array}$ & Social exclusion \\
\hline & $\begin{array}{l}\text { Reduction of labor rights } \\
\text { Weakening of collective bargaining institutions } \\
\text { Changes in working conditions }\end{array}$ & Work \\
\hline & Increased exposure to business cycle fluctuations & Unemployment \\
\hline
\end{tabular}




\begin{tabular}{|c|c|c|}
\hline & \multicolumn{2}{|l|}{ New employment opportunities } \\
\hline & $\begin{array}{l}\text { Changes in the character of social policies (e.g., } \\
\text { minimalist social safety nets) }\end{array}$ & Social support \\
\hline & Increased availability of tobacco & Addiction \\
\hline & Increased availability of unhealthy food & Food \\
\hline & $\begin{array}{l}\text { Increased cost of travel to access healthcare due to } \\
\text { liberalization of prices }\end{array}$ & Transport \\
\hline \multirow{8}{*}{$\begin{array}{l}\text { Privatization of state- } \\
\text { owned enterprises } \\
\text { and natural resources }\end{array}$} & Increased inequality & Social gradient \\
\hline & Work flexibilization & Stress \\
\hline & Changes in households' access to healthcare & Early life \\
\hline & Changed employment conditions in private sector & Work \\
\hline & Mass redundancies & Unemployment \\
\hline & $\begin{array}{l}\text { Increased public revenues in the short term for } \\
\text { potential investment in health } \\
\text { Decreased public revenues in the medium or long } \\
\text { term for potential investment in health } \\
\text { Privatization of health services }\end{array}$ & Social support \\
\hline & $\begin{array}{l}\text { Increased prevalence of addiction linked to stress and } \\
\text { unemployment }\end{array}$ & Addiction \\
\hline & Increases in food prices & Food \\
\hline
\end{tabular}

Source: Author, on the basis of the social determinants listed by Wilkinson and Marmot (2003) and drawing on evidence presented in Hall and Lamont (2013; 2009), Labonté et al. (2009), Marmot and Wilkinson (2006), Marmot et al. (2012), Schrecker (2016), Stuckler and Basu (2013), WHO (2013). 


\section{Box 1. The Origins and Evolution of Structural Adjustment Programs}

Established in 1945, the IMF and the World Bank have a mandate to maintain global financial stability and finance development projects, respectively. To meet this mandate, both organizations became eventually involved in promoting market-liberalizing reforms as part of their lending in support of policy reforms or specific projects (Babb, 2009; Babb and Kentikelenis, 2017). In the late 1970s and 1980s, these IFIs introduced lending programs targeting structural change: Structural Adjustment Loans at the World Bank, and the Structural Adjustment Facility (later, Enhanced Structural Adjustment Facility) at the IMF. These programs became ubiquitous in the 1980s, especially among low-income countries. In the 1990s, structural adjustment programs became staple vehicles for implementing the transition to capitalism in post-communist countries.

By the early 2000s and following extensive criticisms, structural adjustment programs became clad in new rhetoric (Schrecker, 2016): they demonstrated 'flexible' policy design, 'streamlined' conditionality, borrowing-country 'ownership,' and 'pro-poor' orientation (IMF, 2009; World Bank, 2009). Indeed, they were revamped as Poverty Reduction and Growth programs in 1999, and-more recently-as nondescript IMF Extended Credit Arrangements and World Bank Development Policy Loans. After 2009 and the onset of sovereign debt crises in Europe, the IMF-together with European Union institutions-designed so-called Economic Adjustment Programs for troubled European economies (Greece, Ireland, Portugal, and Cyprus). These programs were similar to structural adjustment programs advocated by the Fund and the World Bank in other regions (Greer, 2014), insofar as they relied on extensive market-liberalizing conditionalities.

Recent evidence suggests that newer incarnations of Fund and Bank programs still propagate core elements of the structural adjustment agenda (Schrecker, 2016). The IMF's advertised changes to conditionality have been shown to primarily represent window-dressing, with few departures from the organization's standard market-liberalizing policy advice (Kentikelenis et al., 2016; Ruckert and Labonté, 2012a). The World Bank continues to offer access to loans contingent on the degree of countries' market liberalization (Babb and Kentikelenis, 2017). 


\section{Box 2. The gendered consequences of structural adjustment}

Since UNICEF first drew attention to the gendered impact of structural adjustment (Cornia et al., 1987), considerable academic attention has been devoted to identifying how these policies uniquely and disproportionately affect women and girls. In a direct way, women's health is affected by through changes to health systems. For example, structural adjustment programs are associated with increases in maternal and infant mortality (Coburn et al., 2015b; 2015a; Pandolfelli et al., 2014; C. L. Shandra et al., 2011; Sommer et al., 2015), themselves indicators of inadequate access to healthcare (Nolte et al., 2000).

However, indirect effects of structural adjustment policies on women's health are equally important, and primarily operate through the employment and education pathways. In particular, they are linked to a feminization of the labor force but with widening earnings gaps, and to adverse effects on the informal sector (loss of income or increase in precarity), where women in developing countries are more likely to work (Assaad and Arntz, 2005; Çağatay and Özler, 1995; De Vogli and Birbeck, 2005; Mohindra et al., 2011). In turn, these exposures can result in increases in workrelated health risks and poverty-related illnesses, including infectious diseases (De Vogli and Birbeck, 2005). Further, structural adjustment programs negatively impact women's education (Buchmann, 1996), a key determinant of health status. 